\title{
ANALISIS PIUTANG DAN HUTANG SEBAGAI FAKTOR YANG MEMPENGARUHI LIKUIDITAS PADA PERUSAHAAN LISTRIK MILIK DAERAH KABUPATEN MUSI BANYUASIN
}

\author{
I r s a n \\ Universitas Sjakhyakirti Palembang \\ Email: irsan@unisti.ac.id
}

\begin{abstract}
Perusahaan Listrik Milik Daerah Kabupaten Musi Banyuasin, PT Muba Electric Power (PT MEP) dengan usaha bidang ketenagalistrikan pada tahun 2017 memiliki Current Ratio dengan jumlah aktiva lancar sebanyak 2,5 kali hutang lancar atau setiap 1 rupiah hutang lancar dijamin oleh 2,5 rupiah harta lancar atau 2,5: 1 .

Pada tahun 2017 ini likuiditas perusahaan dikategorikan dalam kondisi sehat. Sedangkan pada tahun 2018 jumlah aktiva lancar sebanyak 0,7 kali hutang lancar atau setiap 1 rupiah hutang lancar dijamin oleh 0,7 kali harta lancar atau 0,7:1.

Kondisi di tahun ini perusahaan dalam kondisi tidak sehat atau kesulitan likuiditas.Quick ratio ideal rata-rata industri senanyak 1 kali, pada tahun 2017 quick ratio PT MEP sebesar 2,5 kali berarti sehat, sedangkan untuk tahun 2018 quick ratio sebesar 0,7 kali jauh di bawah angka 1 berarti tidak sehat.Faktor-faktor penyebab PT MEP kesulitan likuiditas, adalah jumlah piutang usaha yang tidak wajar dan sulit ditagih, junlah hutang yang sangt tinggi terutama pada PT Daruma Mitra Alam dan PT PLN tanpa diimbangi dengan jumlah pendapatan.

Kata Kunci : Piutang, Utang, dan Likuiditas
\end{abstract}

\section{PENDAHULUAN}

\subsection{Latar Belakang Masalah}

Untuk mengukur tingkat kesehatan keuangan perusahaan dapat digunakan alat analisis yang disebut analisis rasio keuangan. Analisis rasio keuangan membantu untuk mengetahui sejauh mana tingkat kinerja keuangan dari suatu perusahaan apakah baik atau sebaliknya. Analisis rasio keuangan yang difokuskan adalah dari tingkat likuiditasnya. Tingkat likuiditas adalah suatu kemampuan yang menunjukkan sejauh mana suatu perusahaan dapat memenuhi kewajiban jangka pendeknya dengan jaminan aktiva lancar yang dimiliki oleh perusahaan tersebut. Likuiditas suatu 
perusahaan dapat menunjukkan seberapa likuid (lancar) dalam melayani perusahaan rekanannya. Rasio likuiditas pada penelitian ini dapat di hitung dengan menggunakan Current Ratio dan Quick Ratio.

Tingkat likuiditas perusahaan dapat dipengaruhi oleh tinggi atau rendahnya piutang usaha. Bagi banyak perusahaan proses penagihan atas piutang adalah suatu pos yang mempunyai peranan penting karena proses ini adalah merupakan tahapan dimana pos piutang akan di konversi menjadi uang kas yang selanjutnya digunakan dalam proses operasi perusahaan pada waktu yang akan datang, termasuk membayar kewajiban atau hutang-hutangnya. Oleh sebab itu, pengendalian pada penagihan piutang sangat perlu selain untuk mengurangi kerugian akibat piutang tak tertagih juga untuk pembiayaan operasinya di masa yang akan datang. Jumlah pelanggan yang banyak membuat pengendalian pun harus dilakukan secara efektif dan secara terus menerus agar proses penagihan piutang perusahaan dapat berjalan dengan lancar. Karena dengan penagihan piutang yang berjalan lancar akan membantu perusahaan untuk dapat menjalankan proses operasinya kembali.

Permasalahan yang terjadi pada Perusahaan Listrik Milik Daerah Kabupaten Musi Banyuasin, PT Muba Electric Power (PT MEP) dengan usaha bidang ketenagalistrikan adalah terganggunya cash flownya, sehingga kesulitan melaksanakan kewajiban-kewajibannya saat jatuh tempo.

\subsection{Perumusan Masalah}

Sesuai dengan judul dan uraian pada latar belakang di atas, maka penulis merumuskan masalah sebagai berikut:

1. Bagaimana kinerja keuangan pada PT Muba Electric Power terhadap tingkat likuiditas dengan menggunakan rumus Current Ratio dan Quick Ratio, pada laporan keuanganperiode 2017-2018?

2. Bagaimana kontribusi pos piutang usaha dan pos hutang usaha terhadap likuiditas perusahaan?

\section{TINJAUAN PUSTAKA}




\subsection{Pengertian Piutang}

Piutang merupakan klaim perusahaan kepada pihak (perusahaan) lain akibat kejadian di waktu sebelumnya dalam bentuk uang, barang, jasaatau dalam bentuk aktiva non kas lainnya yang harus dilakukan penagih (collect) pada tanggal jatuh temponya (Kasmir, 2015:115).

Menurut Standar Akuntansi Keuangan (PSAK No.9), ada dua kategori penggolongan piutang yaitu piutang usaha dan piutang lain-lain. Piutang terdiri atas tiga golongan yaitu piutang dagang (usaha), piutang bukan dagang, dan piutang penghasilan. Piutang dagang merupakan adanya janji lisan dari pembeli untuk membayar barang atau jasa yang dijual yang penagihannya tidak lebih dari satu periode akuntansi.

\subsection{Pengertian Hutang}

Menurut Kieso et. Al (2008:172) hutang adalah "kemungkinan pengorbanan masa depan atas manfaat ekonomi yang muncul dari kewajiban saat ini entitas tertentu untuk mentransfer aktiva atau menyediakan jasa kepada entitas lainnya di masa depan sebagai hasil dari transaksi atau kejadian masa lalu. Hutang merupakan salah satu sumber pembiayaan eksternal atau modal yang berasal dari kreditur yang digunakan oleh perusahaan untuk membiayai kebutuhan dananya. Semakin tinggi tingkat utang, maka bisa menyebabkan pengembalian bagi para pemegang saham biasa menjadi tidak pasti. Munawir (2010:18) berpendapat bahwa "hutang adalah semua kewajiban keuangan perusahaan kepada pihak lain yang belum terpenuhi, dimana hutang ini merupakan sumber dana atau modal perusahaan yang berasal dari kreditor".Tjahjono (2009:152) berpendapat bahwa "hutang adalah kewajiban suatu perusahaan yang timbul dari transaksi pada waktu yang lalu dan harus dibayar dengan kas,barang atau jasa di masa yang akan datang". Sedangkan dalam hal ini Jusup(2005:23) menyatakan bahwa "kewajibanmerupakan hutang yang harusdibayar oleh perusahaan dengan uang atau jasa pada saat tertentu di masa yang akan dating.

\subsection{Klasifikasi Hutang}


Menurut Fahmi (2013:163)hutang dapat diklarifikasikan menjadi dua kelompok yaitu:

\section{Hutang jangka pendek (Short-term liabilities)}

Short term liabilities (hutang jangka pendek) sering disebut juga dengan utang lancar (current liabilities). Penegasan utang lancar karena sumber utang jangka pendek dipakai untuk mendanai kebutuhan-kebutuhan yang sifatnya mendukung aktivits perusahaan yang segera dan tidak bisa ditunda. Dan hutang jangka pendek ini umumnya harus dikembalikan kurang dari satu tahun. a. Hutang dagang (account payable) adalah pinjaman yang timbul karena pembelian barang-barang dagang atau jasa kredit. b. Hutang wesel (notes payable) adalah promes tertulis dari perusahaan untuk membayar sejumlah uang atas perintah pihak lain pada tanggal tertentu yang akan datang ditetapkan (hutang wesel) c.Penghasilan yang ditangguhkan (deferred revenue) adalah penghasilan yang sebenarnya belum menjadi hak perusahaan. Pihak lain telah menyerahkan uang lebih dahulu kepada perusahaan sebelum perusahaan menyerahkan barang atau jasanya d.Kewajiban yang harus dipenuhi (accrual payable) adalah kewajiban yang timbul karena jasa-jasa yang diberikan kepada perusahaan selama jangka waktu tetapi pembayarannya belum dilakukan (misalnya: upah, bunga, sewa, pensiun, pajak harta milik dan lain-lain) e. hutang gaji f. hutang pajak g. dan lain sebagainya.

\section{Hutang Jangka Panjang (long-term Liabilities)}

Long-term Liabilities (hutang jangka panjang) sering disebut dengan utang tidak lacar (non current liabilities). Penyebutan utang tidak lancar karena dana yang dipakai dari sumber utang ini dipergunakan untuk membiayai kebutuhan yang bersifat jangka panjang. Alokasi pembiayaan jangka panjang biasanya bersifat tangiable asset (asset yang bisa disentuh), dan memiliki nilai jual yang tinggi jika suatu saat dijual kembali. Karena itu penggunaan dana utang jangka panjang ini dipakai untuk kebutuhan jangka panjang, seperti pembangunan pabrik, pembelian tanah gedung, dan sebagainya. Adapun yang termasuk dalam kategori utang jangka 
panjang (long-term liabilities) ini adalah: a. hutang obligsi b. wesel bayar c. hutang perbankan yang kategori jangka panjang d. dan lain sebagainnya.

\subsection{Pengertian Likuiditas}

Likuiditas adalah berhubungan dengan masalah kemampuan suatu perusahaan untuk memenuhi kewajiban finansialnya yang segera harus dipenuhi. Jumlah alat-alat pembayaran (alat-alat likuid) yang dimiliki oleh suatu perusahaan pada suatu saat merupakan kekuatan membayar dari perusahaan yang bersangkutan" (Riyanto, 2010: 25). MenurutHani, (2015:121) menyatakan bahwa "likuiditas merupakan kemampuan suatu perusahaan dalam memenuhi kewajiban-kewajiban keuangan yang segera dapat dicairkan atau yang sudah jatuh tempo. Secara spesifik likuiditas mencerminkan ketersedian dana yang dimiliki perusahaan guna memenuhi semua hutang yang akan jatuh tempo".

"Rasio likuiditas merupakan rasio yang mengukur kemapuan perusahaan untuk memenuhi kewajiban financial jangka pendeknya atau Current liabilities... Dengan menghubungkan jumlah kas dam aktiva lancar lain dengan kewajiban jangka pendek bisa memberikan ukuran yang mudah dan cepat dipergunakan dalam mengukur likuiditas. Dua ratio likuiditas yang umum di pergunakan, yaitu current ratio dan quick ratio", (Rambe, dkk. 2015:49)

\subsection{Jenis-jenis Likuiditas}

Likuiditas merupakan rasio yang digunakan untuk mengukur tingkat pengembalian kewajiban lancar pada perusahaan. Likuiditas umumnya diukur dengan perbandingan antara aktiva lancar dengan hutang lancar yang disebut rasio lancar atau current ratio. Namun tidak semua perusahaan yang menggunakan rasio tersebut sebab rasio likuiditas memiliki beberapa alat ukur, seperti Quick ratio, Cash ratio ataupun ratio likuiditas lainnya.

Sedangkan menurut Hani (2015:122) menyatakan bahwa likuiditas dapat diukur menggunakan rasio-rasio, yaitu:1) Current ratio; merupakan alat ukur bagi kemampuan likuidtas yaitu kemampuan untuk membayar hutang yang segera harus 
dipenuhi dengan aktiva lancar. 2) Quick ratio; merupakan alat ukur untuk menilai kemampuan perusahaan dalam membayar gutang yang segera harus di penuhi dengan aktiva lancar yang likuid. 3) Cash ratio; merupakan alat ukur untuk menilai kemampuan perusahaan dalam membayar hutang dengan sejumlah kas yang dimiliki perusahaan.

Dari teori diatas maka dapat di tarik kesimpulan bahwa jenis-jenis rasio likuiditas yaitu Current Ratio, Cash Ratio, dan Quick Ratio. Namun dalam penelitian ini peneliti hanya menggunakan Current Ratio dan Quick ratiosebagai alat ukur dalam menilai tingkat likuiditas perusahaan.

\subsection{Faktor-faktor Yang Mempengaruhi Likuiditas}

Likuiditas merupakan kemampuan suatu perusahaan untuk memenuhi kewajiban keuangannya dalam jangka pendek atau yang segera dibayar. Alat pemenuhan kewajiban keuangan jangka pendek ini berasal dari unsur-unsur aktiva yang bersifat likuid, yakni aktiva lancar dengan perputaran kurang dari satu tahun, karena lebih mudah dicairkan daripada ktiva tetap yang perputarannya lebih dari satu tahun. Menurut Hani (2015:121) faktor-faktor yang dapat mempengaruhi likuiditas adalah unsur pembentuk likuiditas itu sendiri yakni bagian dari aktiva lancar dan kewajiban lancar, termasuk perputaran kas, dan arus kas operasi, ukuran perusahaan, kesempatan bertumbuh (growth opportunities), keragaman arus kas operasi, rasio utang atau struktur utang."

\section{METODOLOGI PENELITIAN}

\subsection{Rancangan Penelitian}

Dalam penelitian ini menggunakan adalah pendekatan deskriptif, yaitu penelitian yang disusun untuk memberikan gambaran secara sistematis tentang informasi ilmiah yang berasal dari subjek atau objek penelitian. Penelitian deskriptif ini bertujuan untuk memberikan gambaran secara sistematis, faktual dan akurat tentang fakta-fakta, sifat-sifat serta hubungan antar fenomena yang diselidiki. 


\subsection{Lokasi Penelitian}

Penelitian dilakukan pada perusahaan listrik pemerintahan daerah kabupaten Musi Banyuaisn dengan nama PT. Muba Electric Power (PT. MEP) beralamat di Jalan Raya Merdeka Sekayu Kabupaten Musi Banyuasin.

\subsection{Metode Pengumpulan Data}

Dalam penelitan ini digunakan teknik dalam pengambilan data adalah data primer, yaitu pengumpulan data dengan cara survey, observasi dan dokumentasi.

\subsection{Metode Analisa Data}

Metode analisis data yang digunakan dalam penelitian ini adalah metode analisis data nonstatistik. Dalam menganalisa data-data unsur-unsur yang digunakan meliputi:sistem pengendalian intern piutang pelanggan PT. Muba Electric Power yang meliputi:

a. Menghitung dan membandingkan current ratio dan quick ratio perusahaan pada laporan keuangan audit tahun 2017 dan 2018.

b. Menganalisa faktor-faktor penyebab perusahaan kesulitan likuiditas

\section{HASIL DAN PEMBAHASAN}

Berdasarkan penelitian dan analisa dokumen laporan keuangan audit perusahaan serta hasil wawancara kepada manajemen perusahaan dan pihak-pihak terkait, penulis menemukan kesenjangan antara besaran piutang udaha, hutang usaha dengan ketersediaan dana sehingga perusahaan selalu kesulitan likuiditasnya. 


\subsection{Analisis Rasio Likuiditas}

Data aktiva lancar dan hutang lancar untuk periode tahun 2017 dan 2018 dapat dilihat

pada table berikut:

Aktiva Lancar Tahun 2017 dan 2018

\begin{tabular}{|c|c|c|c|}
\hline No. & Perkiraan & $\begin{array}{c}\text { Lap. Audit Tahun Lalu } \\
\text { Per 31-12-2017 }\end{array}$ & $\begin{array}{c}\text { Lap. Audit Tahun Lalu } \\
\text { Per 31-12-2018 }\end{array}$ \\
\hline \multicolumn{4}{|c|}{$\begin{array}{l}\text { A. ASETLANCAR } \\
\text { 1. KAS \& EANK }\end{array}$} \\
\hline & Kas Besar Sekayu & 57.735 .000 .00 & 58.335 .488 .00 \\
\hline & Kas Kecil Lalan & 787.276 .00 & $=$ \\
\hline & Bank Mandiri Giro No Rek 113-0004710012 & 418.964 .475 .00 & 11.536 .284 .00 \\
\hline & Bank Mandiri Giro No Rek 113-0007225299 & 254.301 .583 .00 & 130.682 .985 .00 \\
\hline & Bank BRI UJL No Rek.016401000397308 & 118.412 .650 .00 & 12.220 .840 .00 \\
\hline & Bank BRI BP No Rek.018401000398302 & 264.908 .602 .00 & 105.613 .584 .00 \\
\hline & Bank BRI UJL No Rek.016401000403303 & 1.533 .018 .387 .00 & 1.497 .009 .177 .00 \\
\hline & Bank Sumsel No Rek.149-e1-ooees & 1.291 .608 .037 .00 & 1.335 .459 .311 .00 \\
\hline & Bank Sumsel No Rek.149-81-00555 & 3.599 .578 .00 & 10.254 .537 .00 \\
\hline & Bank Sumsel & 1.028 .656 .509 .00 & 22.705 .640 .00 \\
\hline & Bank Sumsel NoRek 149-61-00888 & 461.099 .914 .00 & 340.339 .268 .00 \\
\hline & Bank Negara Indonesia No Rek 271-34-8594 & 9.242 .835 .00 & 554.170 .204 .00 \\
\hline & Jumlah Kas \& Bank .................................. & $5.442 .332 .646,00$ & $4.076 .307 .278,00$ \\
\hline \multicolumn{4}{|c|}{ 2. PIUTANGUSAHA } \\
\hline & Piutang Rekening Listrik Unit Lalan & 1.048 .639 .070 .00 & 5.131 .198 .390 .00 \\
\hline & Piutang Rekening Listrik Curah PLN & 0.00 & 19.427 .766 .478 .00 \\
\hline & Piutang Ragu-ragu & 0.00 & 2.705 .605 .270 .00 \\
\hline & Penyisihan Piutang Rekening Penagih & & 2.200 .430 .090 .00 \\
\hline & Piutang Rekening Listrik Kantor Pus at & 349.222 .968 .00 & - \\
\hline & Piutang Rekening Lis trik Kaja Plakat & 1.580 .296 .029 .00 & $=$ \\
\hline & Piutang Rekening Lis trik Kaja S Keruh & 790.420 .940 .00 & - \\
\hline & Piutang Rekening Listrik Kaja Sido Mukti & 819.331 .301 .00 & $=$ \\
\hline & Piutang Rekening Lis trik Kaja Lais & 1.755 .058 .985 .00 & 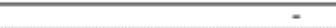 \\
\hline & Piutang Rekening Listrik Kaja Keluang & 2.084 .493 .294 .00 & - \\
\hline & Piutang Rekening Listrik Kaja S Lilin & 1.464 .920 .840 .00 & $=$ \\
\hline & Piutang Rekening Listrik Kaja Bayung Lincir & 753.893 .915 .00 & - \\
\hline & Piutang Rekening Listrik Kaja Tungkal Jaya & 1.382 .168 .632 .00 & - \\
\hline & Piutang Rekening Listrik 3 Phase & 5.797 .698 .00 & - \\
\hline & Jumlah Piutang Ditahun berjalan & 12.014 .043 .652 .00 & 29.465 .000 .228 .00 \\
\hline & Piutang Ditahun sebelumnya & & \\
\hline & Piutang Rekening Listrik Curah PLN & 11.790 .265 .247 .00 & - \\
\hline & Piutang Rekening Lis trik Unit Lalan & 1.028 .903 .374 .00 & - \\
\hline & Piutang Rekening Listrik Denda Curah & 28.010 .911 .00 & - \\
\hline & Jumlah piutang tahun sebelumnya & 12.847 .179 .532 .00 & - \\
\hline & Jumlah Piutang Usaha .............................. & $24.861 .223 .184,00$ & $29.465 .000 .228,00$ \\
\hline \multicolumn{4}{|c|}{ 3. PIUTANG BERELASI } \\
\hline & PT. PETRO MUBA & 3.185 .547 .000 .00 & 3.271 .747 .000 .00 \\
\hline & PT. MUBA Link & & 25.000 .000 .00 \\
\hline & PT. MUBASARANA & 5.000 .000 .00 & 5.000 .000 .00 \\
\hline & Jumlah & $3.190 .547 .000,00$ & $3.301 .747 .000,00$ \\
\hline \multicolumn{4}{|c|}{ 4. PIUTANGLAIN-LAIN } \\
\hline & Piutang PLN & 200.000 .000 .00 & 200.000 .000 .00 \\
\hline & Piutang PT Tambora & 53.325 .000 .00 & - \\
\hline & Piutang Karyawan & 847.373 .469 .00 & 839.173 .480 .00 \\
\hline & Piutang Lain-Lain & 2.544 .340 .956 .00 & 51.500 .001 .00 \\
\hline & Piutang Pihak Ketiga & 100.000 .000 .00 & - \\
\hline & Jumlah & $3.745 .039 .425,00$ & $1.090 .673 .461,00$ \\
\hline \multicolumn{4}{|c|}{ 5. PERSEDIAAN } \\
\hline & Solar & 79.989 .147 .00 & 379.186 .546 .00 \\
\hline & Pelumas & 8.712 .109 .00 & 5.394 .209 .00 \\
\hline & LVTC. LC. SWC & 0.00 & $=$ \\
\hline & KWH Meter & 39.104 .000 .00 & 149.902 .594 .00 \\
\hline & Ar Accu & 108.100 .00 & 108.100 .00 \\
\hline & Jumlah Persediaan............. & $127.913 .356,00$ & $534.571 .449,00$ \\
\hline \multicolumn{4}{|c|}{ laya Dibayar Dimuka } \\
\hline & - Uang Muka Pajak (PPh Pasal 21 & 11.604 .000 .00 & - \\
\hline & - Uang Muka Biaya Kendaraan & 40.000 .000 .00 & $=$ \\
\hline & - Biaya Dibayar dimuka (Sewa Gedung) & - & 90.137 .592 .00 \\
\hline & Jumlah Uang Muka & $51.604 .000,00$ & $90.137 .592,00$ \\
\hline & & & 24 \\
\hline & Jumlah Aset Lancar & $37.418 .659 .611,00$ & $38.558 .437 .008,00$ \\
\hline
\end{tabular}


Hutang Lancar Tahun 2017 dan 2018

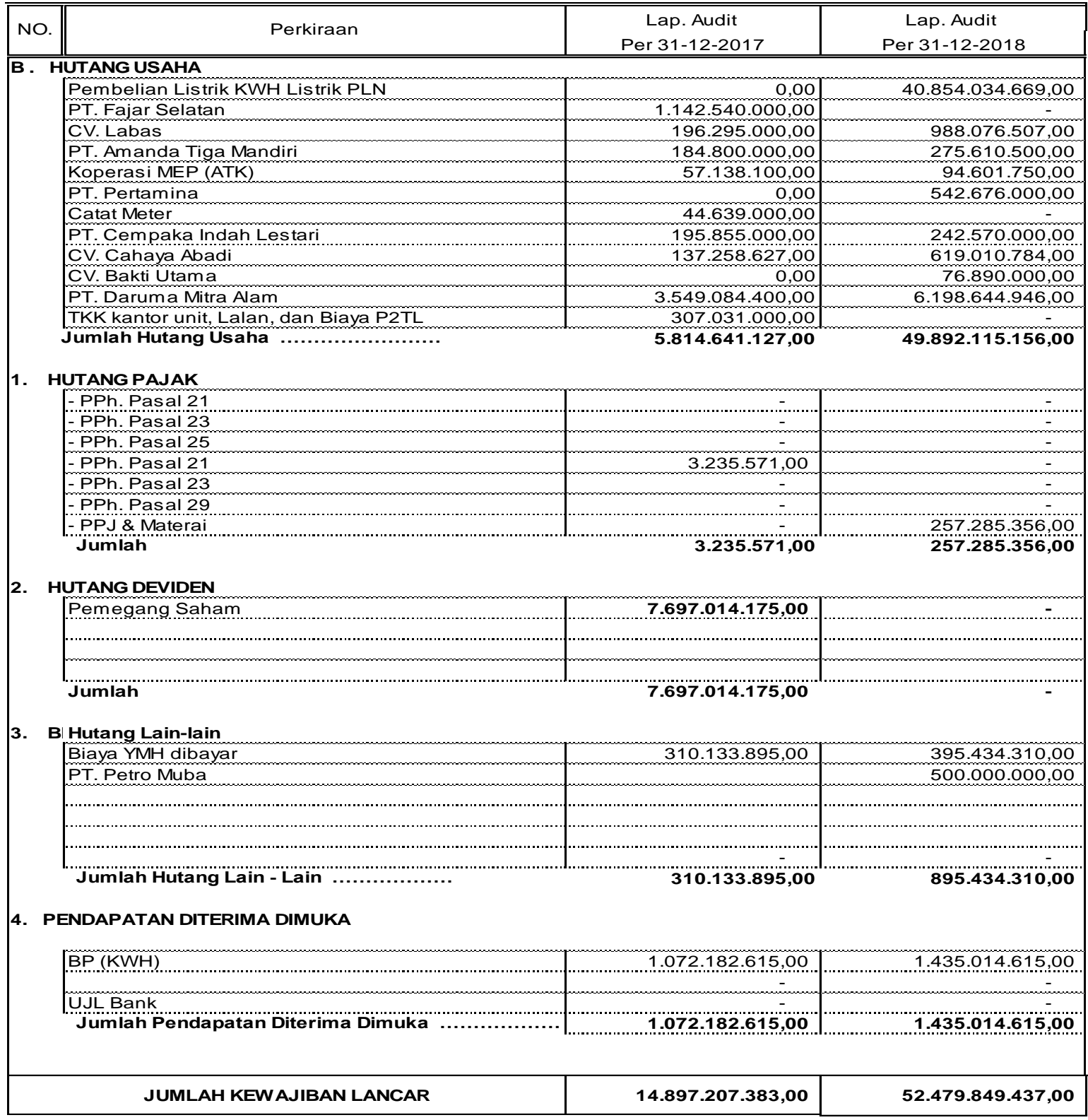

a. Current Ratio (CR) ; digunakan untuk mengukur kemampuan perusahaan membayar kewajiban jangka pendek atau hutang yang segera jatuh tempo pada saat ditagih.

Current Ratio $=$ Aktiva Lancar $/$ Hutang Lancar 
Tahun 2017, Current Ratio $=$ Rp37.418.659.611/Rp14.897.207.383 = 2,5 kali

Tahun 2018, Current Ratio $=\operatorname{Rp38.558.437.008/Rp52.479.849.437=0,7~kali~}$

Dari perhitungan di atas dapat dijelaskan bahwa pada tahun 2017 jumlah aktiva lancar sebanyak 2,5 kali hutang lancar atau setiap 1 rupiah hutang lancar dijamin oleh 2,5 rupiah harta lancar atau 2,5 : 1.Pada tahun 2017 ini likuiditas perusahaan dikategorikan dalam kondisi sehat. Sedangkan pada tahun 2018 jumlah aktiva lancar sebanyak 0,7 kali hutang lancar atau setiap 1 rupiah hutang lancar dijamin oleh 0,7 kali harta lancar atau $0,7: 1$. Kondisi di tahun ini perusahaan dalam kondisi tidak sehat atau kesulitan likuiditas.

b. Quick Ratio ; rasio uji cepat yang menunjukkan kemampuan perusahaan membayar kewajiban jangka pendek dengan aktiva lancar tanpa memperhiyungkan persediaan. Hal ini disebabkan persediaan memerlukan waktu relative lama untuk diuangkan dibandingkan dengan asset lain.

Quick Ratio $=\quad($ Aktiva Lancar - Persediaan $) /$ Hutang Lancar

Untuk tahun 2017 :

Quick Ratio $=(\operatorname{Rp} 37.418 .659 .611-\mathrm{Rp} 127.913 .356) / \mathrm{Rp} 14.897 .207 .383=2,5 \mathrm{kali}$

Untuk tahun 2018 :

Quick Ratio $=(\operatorname{Rp} 38.558 .437 .008-\operatorname{Rp} 534.571 .449) / \operatorname{Rp} 52.479 .849 .437=0,7$ kali

Dari perhitungan di atas dapat dijelasakan bahwa jika rata-rata industri 1 kali, pada tahun 2017 quick ratio sebesar 2,5 kali berarti sehat, sedangkan untuk tahun 2018 quick ratio sebesar 0,7 kali jauh di bawah angka 1 berarti tidak sehat.

\subsection{Faktor-faktor yang Mempengaruhi Likuiditas Perusahaan ditinjau dari}

\section{sudut Piutang dan Hutang}

Dari sudut piutang, laporan keuangan tahun 2017 menunjukkan piutang sebesar Rp24.861.223.184,- dan pada tahun 2018 piutang menunjukkan angka sebesar Rp29.465.000.228,-. Angka ini terlalu tinggi jika dibandingkan dengan 
rata-rata penjualan rekening listrik perbulan, yang mana rata-rata penjualan rekening listrik pada tahun 2017 sebesar Rp4.931.624.051,- dan pada tahun 2018 sebesar Rp 6.556.434.035,-. Sehingga piutang usaha tahun 2017 dan 2018 terjadi ketidakwajaran yaitu sebesar $1.200 \%$ dari data-rata penjualan rekening per bulan. Berdasarkan pengamatan dan wawancara penulis pada pihak manajemen didapatkan bahwa sulitnya untuk menagih piutang pada pelanggan ada banyak faktor, antara lain kurangnya kesadaran pelanggan akan membayar rekening listrik, jauhnya loket pembayaran dengan tempat tinggal masyarakat mengingat pelanggan listrik merupakan masyarakat pedesaan yang lokasinya sangat berjauhan., dan beberapa kecurangan yang dimanfaatkan dari pihak penagih yang menggunakan uang tagihan listrik dari system ofline. Beberapa usaha yang telah dilakukan manajemen PT MEP dalam penagihan rekeniing listrik antara lain mengadakan kerjasama dengan kantor Pos, Bank Sumsel Babel, BRI, Bumdes, dan beberapa perusahaan atau pihak ketiga, namun piutang usaha belum menunjukkan penurunan yang signifikan. Ketidakmampuan manajemen mengatasi masalah piutang ini memberikan kontribusi atas terganggunya likuiditas cash flow terutama untuk memenuhi kewajiban-kewajibannya saat jatuh tempo.

Dari sudut hutang. laporan keuangan tahun 2017 menunjukkan hutang lancar sebesar Rp14.897.207.383,- dan pada tahun 2018 hutang lancar menunjukkan angka sebesar Rp52.479.849.437,-Kenaikan hutang yang sangat signifikan pada tahun 2018 didominasi oleh hutang pada PT Daruma Mitra Alam (PT DMA) dan PT PLN. PT DMA merupakan perusahaan yang bekerjasama operasi PLTD 2 X 1 MW selama 12 jam per hari di Kecamatan Lalan,yang mana PT MEP membeli daya listrik pada PT DMA tersebut sejak bulan September 2017. Posisi hutang PT MEP per 31 Desember 2017 sebesar Rp3.549.084.400,-. Sedangkan pada tahun 2018 sebesar Rp6.198.644.946,-. Kerjasama operasional ini merugikan perusahaan karena tidak sebanding dengan penerimaan rekening listrik unit Lalan, sehingga setiap bulan perusahaan menanggung kerugian sebesar Rp2.000.000.000,- Sejak awal kerjasama operasi ini manajemen PT MEP mengetahui akan mengalami kerugian 
yang besar, namun untuk mengurangi jam operasi dalam rangka menekan biaya operasional manajemen tidak dapat melakukannya karena adanya intervensi dari pemerintah daerah selaku pemegang saham.

Sedangkan PT PLN merupakan perusahaan yang menjual kWh dengan system curah kepada PT MEP yang kemudian didistribusikan kepada pelanggan. Hutang pada PT PLN pada tahun 2017 sebesar nol rupiah sedangkan pada tahun 2018 sebesar Rp40.854.034.669,- Hal ini karena terjadi kenaikan Tarif Dasar Listrik (TDL) PT PLN dengan faktor kali $\mathrm{Q}=1,01$ menjadi $\mathrm{Q}=1,75$ menyebabkan kenaikan TDL PLN yang semula Rp714,07/kWh menjadi Rp 1.237,25/kWh. Sementara harga jual PT MEP kepada pelanggan tetap harga semula yaitu Rp850/kWh. Hal ini berlangsung dari bulan Februari 2018 sampai dengan Oktober 2018. Pada bulan Nopember 2018 baru dilakukan penyesuaian harga jual per kWh PT MEP kepada pelanggan setelah terbitnya Peraturan Bupati Musi Banyuasin tentang penyesuaian harga TDL PT MEP. Untuk menghindari kerugian dan kesulitan cash flow yang semakin dalam seharusnya manajemen PT MEP menaikkan TDL kepada pelanggannya setelah PT PLN menaikkan TDL kepada PT MEP, namun tidak dapat dapat dilakukan oleh manajemn terkait Peraturan Bupati (Perbub) yang belum turun. Hal ini juga adanya intervensi pemerintahan daerah untuk menghindari gejolak di masyarkat atas kenaikan TDL dalam rangka menghadapi pemilihan gubernuur tahu 2018.

\section{KESIMPULAN DAN SARAN/ REKOMENDASI}

\subsection{Kesimpulan}

Pada bagian terakhir ini penulis menarik beberapa kesimpulan dari hasil analisis sebagai berikut :

1. Current Ratio pada tahun 2017 jumlah aktiva lancar sebanyak 2,5 kali hutang lancar atau setiap 1 rupiah hutang lancar dijamin oleh 2,5 rupiah harta lancar atau 2,5 : 1. Pada tahun 2017 ini likuiditas perusahaan dikategorikan dalam 
kondisi sehat. Sedangkan pada tahun 2018 jumlah aktiva lancar sebanyak 0,7 kali hutang lancar atau setiap 1 rupiah hutang lancar dijamin oleh 0,7 kali harta lancar atau $0,7: 1$. Kondisi di tahun ini perusahaan dalam kondisi tidak sehat atau kesulitan likuiditas.

2. Quick ratio ideal rata-rata industri senanyak 1 kali, pada tahun 2017 quick ratio PT MEP sebesar 2,5 kali berarti sehat, sedangkan untuk tahun 2018 quick ratio sebesar 0,7 kali jauh di bawah angka 1 berarti tidak sehat.

3. Faktor-faktor penyebab PT MEP unlikuiditas, adalah jumlah piutang usaha yang tidak wajar dan sulit ditagih, junlah hutang yang sangt tinggi terutama pada PT DMA dan PT PLN tanpa diimbangi dengan jumlah pendapatan.

\subsection{Saran}

1. Untuk meningkatkan likuiditas cash flow perusahaan, manajemen harus memaksimalkan penagihan piutang pelanggan dengan cara lebih tegas dan refresif dengan bekerjasama dengan pihak kepolisian, apabila pelanggan menunggak selama tiga bulan harus diputus sementara tanpa toleransi sampai pelanggan melunasinya akan disambung kembali.

2. Apabila pihak pemegang saham melakukan intervensi dalam hal kebijakan bisnis yang diprediksi akan merugikan perusahaan, jajaran direksi harus tegas menolak atau bahkan harus siap untuk mundur dari jabatan tersebut.

\section{DAFTAR PUSTAKA}

Fahmi, Irham. 2014.Analisis Laporan Keuangan. Bandung: Alfabeta.

Hani. Syafriida. 2015. Teknik Analisa Laporan Keuangan. Medan: UMSU PRESS.

Jusup. Al Haryono. 2005. Dasar-Dasar Akuntansi, Edisi 6. Yogyakarta: Sekolah Tinggi Ilmu Ekonomi YKPN.1

Kasmir. 2014. Analisis Laporan Keuangan. Edisi Satu. Cetakan Ketujuh. Jakarta : PT Raja Grafindo Persada. 
Kieso. Donald. E, Jerry J, Weygandt, Terry D.Warfield. 2008. Akuntansi Intermediate. Edisi 12. Jakarta: Erlangga.

Munawir. (2010). Analisis Laporan Keuangan, Edisi 4, Yogyakarta:Liberty.

Rambe dkk. 2015. Analisis Pengaruh Corporate Social Responsibility, Profitabilitas dan Ukuran Perusahaan Terhadap Nilai Perusahaan Pada Perusahaan Perkebunan Yang Go Public Di Indonesia, Malaysia, dan Singapura. Simposium Nasional Akuntansi 18 UniversitasSumatera Utara, Medan.

Riyanto. Bambang. 2010. Dasar-Dasar Pembelanjaan Perusahaan, ed. 4, Yogyakarta: BPFE.

Standar Akuntansi Keuangan (PSAK No.9),

Tjahjono. Achmad dkk. 2009. Akuntansi Suatu Pengantar 2,Cetakan1.Yogyakarta: Ganbika. 